\title{
AESTHETICS, AUTHORITY
}

\section{AND THE OUTLAW OF THE STREET}

\author{
Susan Bird ${ }^{1}$
}

This is a paper about the meanings of aesthetics, authority, street art, and graffiti. It is about the potential that graffiti has to disrupt the codes that emanate from the post-industrial, capitalist city, and the ways in which law making authorities have attempted to curb that potential. The regulation of public space involves control over the visual appearance of that space. The Graffiti Prevention Act (Vic) 2007 is one instrument employed in regulating the aesthetics of space. The legislation defines street art as illegal and imposes harsh penalties for the creators of this form of public art. As Margaret Davies writes in Asking the Law Question, the illegality of an act cannot be seen at face value - it is only after we see the act through the filter of the law that it is seen as criminal. ${ }^{2}$ I use this as a starting point in asking why graffiti is a criminal act.

The illegality of street art is often linked to its location, or what Tim Cresswell refers to as 'the crucial "where" of graffiti'. ${ }^{3}$ When taken off the street, and into the gallery, it is art. On the street, it is crime. Here, issues such as permanence and permission also come into play. Where street art mimics aspects of more traditional forms, such as permanency, it may become acceptable and become highly valued culturally and financially. In this paper I ask:

\footnotetext{
${ }^{1} \mathrm{PhD}$ student at Victoria University, Melbourne. All photos used are the author's own.

${ }^{2}$ Margaret Davies, Asking the Law Question ( $3^{\text {rd }}$ ed, 2008) Lawbook Co, Pyrmont.

${ }^{3}$ Tim Creswell, 'The Crucial "Where" of Graffiti' in In Place/Out of Place: Geography, Ideology, Transgression (1996) University of Minnesota Press, Minneapolis.
} 
How and why does the Graffiti Prevention Act work to support a particular aesthetic by controlling street art? I will examine how the Melbourne City Council's attempt to preserve street art was overcome by this Act, which I argue enforces the homogenised production of space and an 'aesthetic of authority." $\mathrm{I}$ will also critique $D P P v$ Shoan, ${ }^{5}$ a case that considered whether Shoan's artistic reconfiguration of space ought to be punished with a term in jail.

Legal responses to graffiti are overly punitive and must be interrogated, rather than the constant analysis of the artists and their reasons for 'offending'. What must be considered is

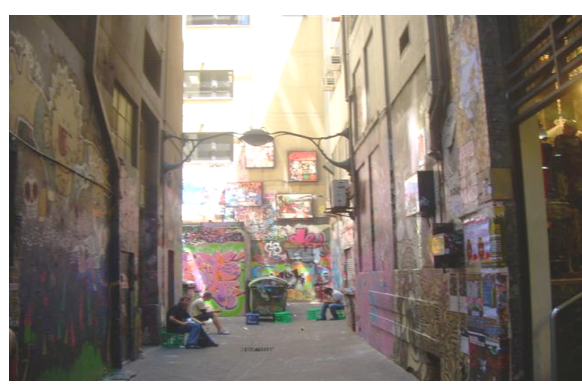

Figure 1 Centre Place, Melbourne why street art motivates such a strong response. I contend that graffiti arouses such a response because it changes the way we experience the city. It causes an interruption to a commercialised system of signs and codes. It offers a possibility of difference and exposes cracks in the ordered routine of everyday life. Street art conveys a lifestyle that baffles those driven by a world of economy. It takes inhabitants on a treasure hunt to unknown places where countless gifts of creative, unexpected inspiration lie in wait.

As Mark Halsey and Alison Young write, '...it is no exaggeration to say that the State has a marked and ongoing interest in the flow of paint. ${ }^{96}$ In the postmodern era the capitalist system works more through systems of signs and meanings and less through ownership and production. Control is maintained via influencing subjectivity through the management of messages and creation of desires. Felix Guatarri argues that we live in an age of 'Integrated

\footnotetext{
${ }^{4}$ Jeff Ferrell, Crimes of Style: Urban Graffiti and the Politics of Criminality (1996) Garland, New York, p178. ${ }^{5}$ DPP v Shoan [2007] VSCA 220.

${ }^{6}$ Mark Halsey and Alison Young (2006) 'Our Desires are Ungovernable' Theoretical Criminology 10(3), p295. 
World Capitalism' (or IWC). ${ }^{7}$ Here, nothing can exist outside of capitalism or beyond its system of signs. In this sense, graffiti is a part of capitalism and is born of it. However, it also resists it. This resistance is at the level of meaning, where graffiti may confuse the messages found within public space. In this way, graffiti interrupts what Jeff Ferrell refers to as 'the aesthetic of authority' - or the neat and tidy space produced by capitalism. ${ }^{8}$ Halsey and Young write 'Historically, and significantly, the modern state has sought to transform smooth and nomadic territories into places where everything is ordered, numbered, monitored and controlled. ${ }^{9}$ The state produces a capitalist spatiality, geared toward consumption. ${ }^{10}$ It is homogenised, and seeks to subsume all difference within its midst. ${ }^{11}$ As Henri Lefebvre writes, 'What is different...is excluded....the existing centre and the forces of homogenisation must seek to absorb all differences... ${ }^{12}$ The city street loses its local character and becomes more like an airport. ${ }^{13}$ Jean Baudrillard asserts that 'The urban city is...a neutralised, homogenised space, a space where indifference, the segregation of urban ghettos, and the downgrading of districts, races and certain age groups are on the increase. ...[The city is] an immense centre for marshalling and enclosure where the system reproduces itself not only economically and spatially, but also in depth by the ramifications of signs and codes, by the symbolic destruction of human relations. ${ }^{14}$

\footnotetext{
${ }^{7}$ Felix Guattari (1989) 'The Three Ecologies' New Formations Number 8 Summer.

${ }^{8}$ The relationship between street art and capitalism is never straight forward. Graffiti parodies commercial art and can be a form of playful political action in public space. Graffiti is also commodified by capitalism, becoming a valuable art object.

${ }^{9}$ Halsey and Young at n 6, p295.

${ }^{10}$ Henri Lefebvre, The Production of Space (1991) Blackwell Oxford.

${ }^{11}$ Ibid p373.

${ }^{12}$ Ibid.

${ }^{13}$ Architect Rem Koolhaas writes that cities are becoming more characterless. See Koolhaas in Liven de Cauter, The Capsular Civilization: On The City in the Age of Fear (2004) NAi Publishers, New York, p11.

${ }^{14}$ Jean Baudrillard (1993) 'Kool Killer, or The Insurrection of Signs' Symbolic Exchange and Death Sage, London, p77.
}

Public Space: The Journal of Law and Social Justice (2009) Vol 3, Art 3, p1-24. 
Authority dictates that graffiti has no place in the sanitised, commercial city. As Jeff Ferrell writes: ‘...graffiti threatens not only the economic value of private property, and the political control of property and space, but the sense of ordered style, the aesthetic of authority, that is intertwined with them. When those in authority assign epistemic and aesthetic traits to graffiti, they reveal in the process their own sense of beauty, meaning and power.' 15 The political power of graffiti, Baudrillard writes, derives from its ability to 'derail the

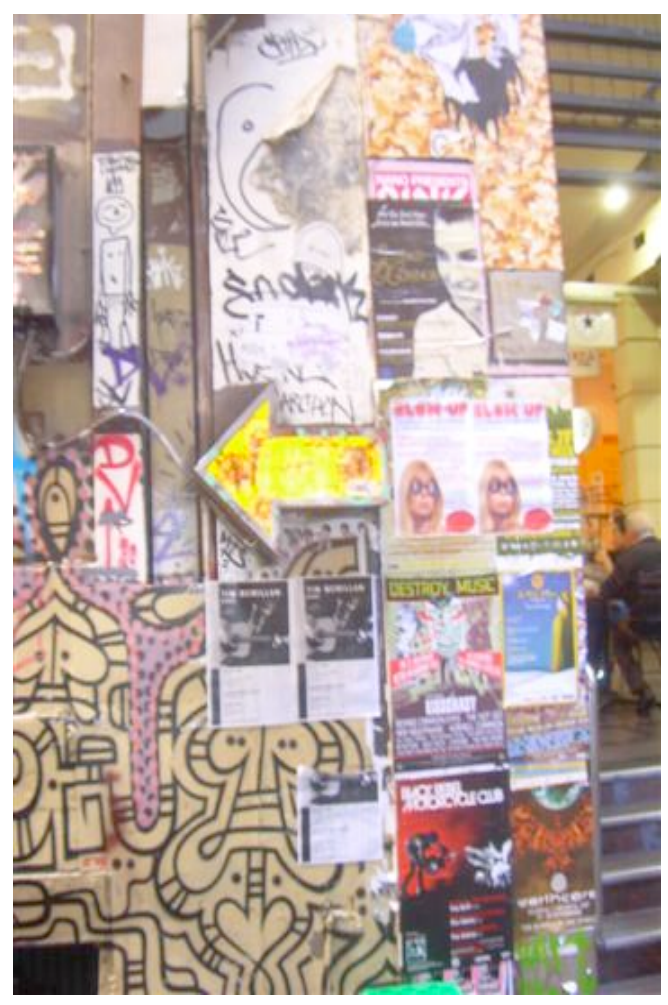
common system of designations. ${ }^{, 16}$ As he explains, in the postmodern era the city has become a location of signs and signification rather than a place of industry and production. The city is a space dense with meanings and messages. For Baudrillard, graffiti disrupts a city which cannot make sense of it. Within the high capitalist city, graffiti is empty of meaning. ${ }^{17} \mathrm{He}$ writes that graffiti is '...like a scream, an interjection, an anti-discourse, as the waste of all syntactic, poetic and political development, as the smallest radical element that cannot be caught by any organised discourse.....with neither connotation nor denotation, [graffiti] escape[s] the principle of signification and, as empty signifiers, erupt[s] into the sphere of the full signs of the city, dissolving it on contact. ${ }^{18}$

The criminalisation of Noam Jason Shoan, or ugly renderings on the blank canvas of Melbourne

I began considering these issues in August 2007 before the Graffiti Prevention Act came into force. I was sitting in my office at university after teaching tutorials. Someone had discarded

\footnotetext{
${ }^{15}$ Ferrell n 4, p179.

${ }^{16}$ Baudrillard n 14, p78.

${ }^{17}$ Ibid p 77.

${ }^{18}$ Ibid p78-9.
}

Public Space: The Journal of Law and Social Justice (2009) Vol 3, Art 3, p1-24. 
a copy of the Herald-Sun (Melbourne's daily pictorial newspaper), leaving it on the desk for any academic wanting some light relief from the usual fare of Foucault, Derrida or the musty old judgments of the English Law Lords. Normally I would avoid this paper, but the headline 'Jail for Graffiti' boldly jumped off the front page. A 25 year old artist, Noam Jason Shoan had been sentenced to 3 months imprisonment for a 5 year 'career' of unauthorised painting in public spaces. Immediately I was struck by the very heavy penalty for what was merely an alteration of aesthetic. This led me to question: who chooses the aesthetic of public space? Are Victorians regularly jailed for altering the appearance of their local environment with a spray can?

A search of a case database revealed that there are very few reported Victorian cases that contain the word 'graffiti'. DPP $v$ Shoan ${ }^{19}$ stands out as the only reported criminal case on 'graffiti'. Originally heard in the Magistrates' Court, the recorded case is an appeal to the Supreme Court. The case was first heard by Magistrate Sarah Dawes who imposed a penalty of 250 hours community service and ordered that a fine of $\$ 30,000$ be paid to transport providers whose infrastructure Shoan was found guilty of damaging. Magistrate Dawes did not convict Shoan on the grounds that he was remorseful, and that a conviction would unfairly burden his future career as a graphic artist. ${ }^{20}$ However, although $\$ 30,000$ was a hefty fine, the prosecution appealed the case to the County Court arguing that the punishment was too lenient, as Shoan had not had a conviction recorded. ${ }^{21}$ In the County Court, Shoan was convicted and sentenced to three months imprisonment. The presiding judge, Wood J, stated that graffiti was 'affronting community standards' 22 and should therefore be severely

\footnotetext{
${ }^{19}$ DPP v Shoan [2007] VSCA 220.

${ }^{20}$ Brendan Roberts, 'Jail for Graffiti' Herald-Sun August 23, 2007.

${ }^{21}$ This is likely due to pressure from groups such as PALS (People Against Lenient Sentencing) and RAGE (Residents Against Graffiti Everywhere).

${ }^{22}$ Kate Jones, 'Graffiti Vandal "now Bird Watcher"” Herald-Sun August 4, 2007.
} 
punished. Shoan had originally pleaded guilty to charges of 42 counts of criminal damage which allegedly cost nearly $\$ 52,000$ to 'rectify'. ${ }^{23}$

On the same day as the Herald-Sun reported 'JAIL FOR GRAFFITI', debate in Victorian Parliament turned to the topic of Noam Shoan. The member for Bass commented on the judgement:

I want to congratulate Judge Tim Wood on overturning a decision of a magistrate. He jailed a graffiti artist, or vandal, Noam Shoan, for graffitiing railway property... In congratulating Judge Tim Wood I must condemn the magistrate, Sarah Dawes, for the way in which she said a conviction may interfere with the graffiti vandal, Noam Shoan, working overseas as a graphic artist. Too bad! ... These people are not artists, they are vandals, and they should be treated as such. Well done to Judge Tim Wood! There should be more judges and magistrates like him who reflect the community's will and desire to see these people treated in the way they should be treated. Stick them in jail: they cannot do the damage there. ${ }^{24}$

After Wood J's sentence was handed down in the County Court, the case went on appeal to the Full Supreme Court. Here, Buchannan, Nettle and Curtain JJ heard that Shoan had been denied procedural fairness as the defence had not been aware that imprisonment was under contemplation by the judge. Because of this breach, the appeal was allowed. Upon reconsidering Shoan's sentence, Buchannan J, in the major judgment, discusses Shoan's alterations to the aesthetic of the cityscape:

The damage inflicted by the applicant on publicly owned property and property in the public view was considerable. It could be said he defaced and rendered ugly a great deal of the scenery that people pass by. At the very least, he unilaterally imposed his

\footnotetext{
${ }^{23}$ DPP v Shoan [2007] VSCA 220 [3].

${ }^{24}$ Victoria Parliamentary Debates, Legislative Assembly, 23 August 2007, 2936 (Ken Smith).

Public Space: The Journal of Law and Social Justice (2009) Vol 3, Art 3, p1-24.
} 
notions of art and decoration on the rest of the world. He did so persistently over a period of some five years. ${ }^{25}$

Justice Buchanan asserts that Shoan 'unilaterally imposed his notions of art and decoration on the rest of the world.' (Art and decoration are an individualistic judgment of taste.) ${ }^{26}$ Buchannan's comment could be applied to any 'man-made' alteration to space - any deviation from its natural appearance. Streets, houses, power-lines - all inflict the passer-by with a particular aesthetic. The placement of signage, one example being billboards, could be likened to the aesthetic of a mural. A billboard is often brightly coloured and intrusive; its imagery may be an 'affront' to community standards of aesthetic taste (often also offensive on other levels). Yet the eradication of billboards is rarely contemplated ${ }^{27}$ and where Melbourne City Council has considered restricting billboards to certain locations, these proposals have been overcome by commercial forces. It appears that money can buy an individual the right to alter the aesthetic of public space - as long as the messages presented are

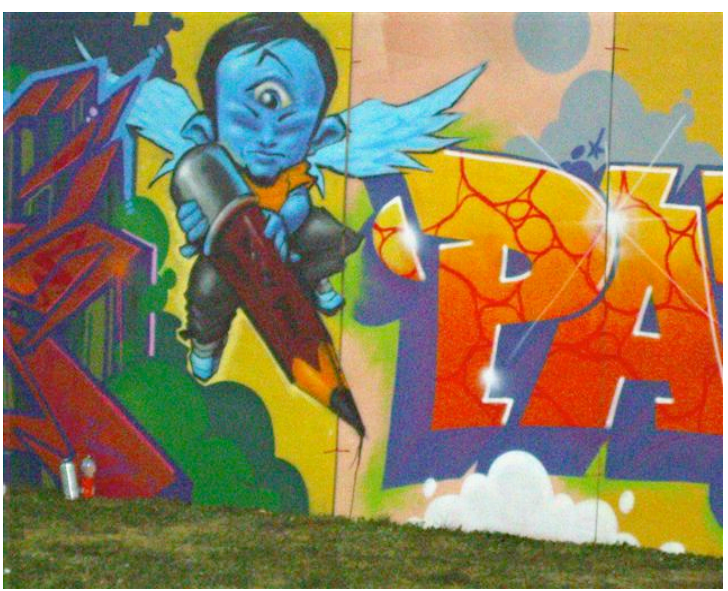

Figure 2 Art at Don't Ban the Can Protest Melbourne, 21/10/2008 aimed at encouraging the frenzied sale of consumer products. ${ }^{28}$

\footnotetext{
${ }^{25}$ DPP v Shoan [2007] VSCA 220 [28] per Buchanan J (my emphasis).

${ }^{26}$ Carolyn Korsmeyer (ed) Aesthetics: The Big Questions (1999) Blackwell, Oxford.

27 São Paulo, the second-largest city in Brazil, has enforced a billboard ban since January 2007. See http://www.businessweek.com/innovate/content/jun2007/id20070618 505580.htm?chan=top+news top+news+ index innovation $+\% 2 \mathrm{Bamp} \% 3 \mathrm{~B}+$ design . Auckland has also considered a billboard ban, which was slammed as an encroachment on free speech. See http://www.freespeech.org.nz/section14/2006/12/13/auckland-wants-toban-billboards/

${ }^{28}$ As Ron English, billboard liberator, sees himself as Robin Hood - taking commercial space from corporations and giving it back to the people. English asks: 'Who gets to own the visual space that we all share?' Triple J TV Australian Broadcasting Commission, broadcast 24/4/09
} 


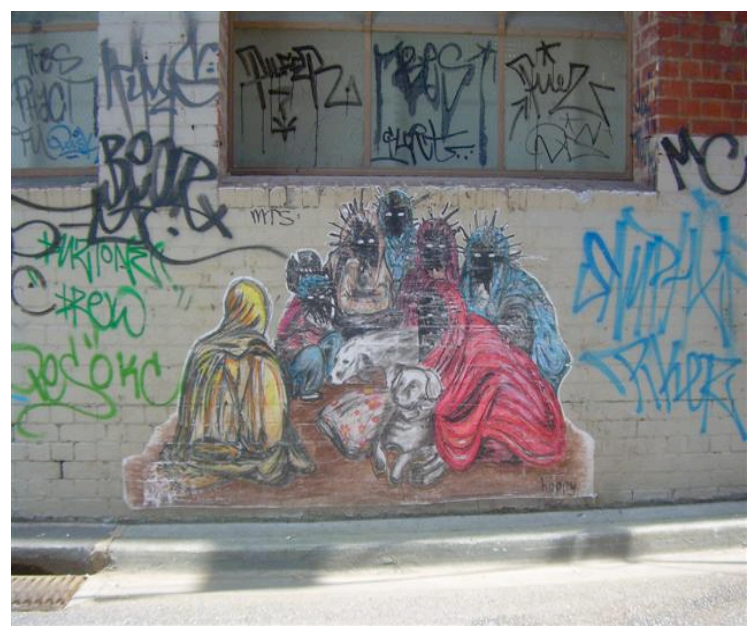

Graffiti is art that introduces creative elements that are not usually motivated by financial gain, and often present messages which oppose concepts of private property, 'cleanliness', and consumerism. As Ferrell writes: 'Graffiti exists as a public art outside the circle of corporate style and consumption. Graffiti

\section{Figure 3 Graffiti Nativity Scene}

illuminates the city... it stands for a sort of decentralised and decentred insubordination, a mysterious resistance to conformity and control, a stylish counterpunch to the belly of authority. ${ }^{29}$ It is within this resistance that graffiti is so threatening.

The conclusion reached by Buchanan, Nettle and Curtain JJ in Shoan v DPP was that Shoan's artwork was ugly, unwanted vandalism. However, although the court found that 3 months jail was within a possible range of sentences for such damage, they could see 'no utility in requiring the applicant to serve any further term of imprisonment ${ }^{30}-$ and the remainder of his sentence was suspended for 6 months.

While Noam Shoan's punishment for graffiti was debated in Melbourne's courtrooms, outside street art flourished. Melbourne was becoming increasingly well known for its laneway 'galleries'. Shoan was not the only Melbournian with a desire to make unauthorised alterations to the aesthetic of the city. Rather than facing condemnation, many artists were being recognised for their talent and creativity. In court, street art was a serious crime outside it was increasingly a commodity.

\footnotetext{
${ }^{29}$ Jeff Ferrell n 4, p197

${ }^{30}$ DPP v Shoan [2007] VSCA 220 [29] per Buchanan J.
} 


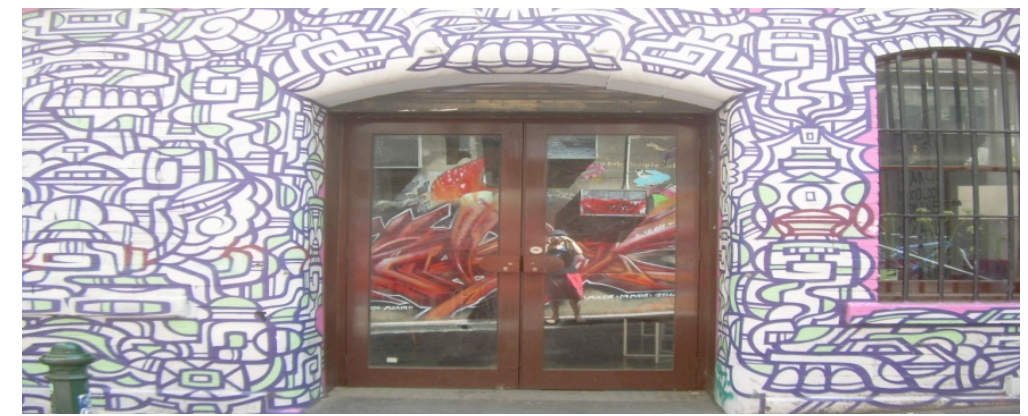

Figure 4 Hosier Lane, Melbourne

Street artists such as Banksy and Shepard Fairy have gained fame and commercial success in part though the sale of books which contain photos of their illegal works. Street art-styled pieces have also been sold for high prices to celebrities such as Angelina Jolie, the 'trendiness' of the art amplified by artist's 'street' (or illegal) presence. Street art has been repackaged as a consumer good, and used to sell products - including Melbourne itself. Melbourne's international reputation as a street art hub was increasingly being recognised on the internet, and via books such as Stencil Graffiti Capital: Melbourne, published by New York publisher Mark Batty. ${ }^{31}$ Tourist organisations, for example, Lonely Planet, declare that Melbourne's top cultural attraction is its laneways, complete with brightly coloured murals. ${ }^{32}$ Marcus Westbury, art curator and event manager, hosted a TV show Not Quite Art which featured an episode exploring

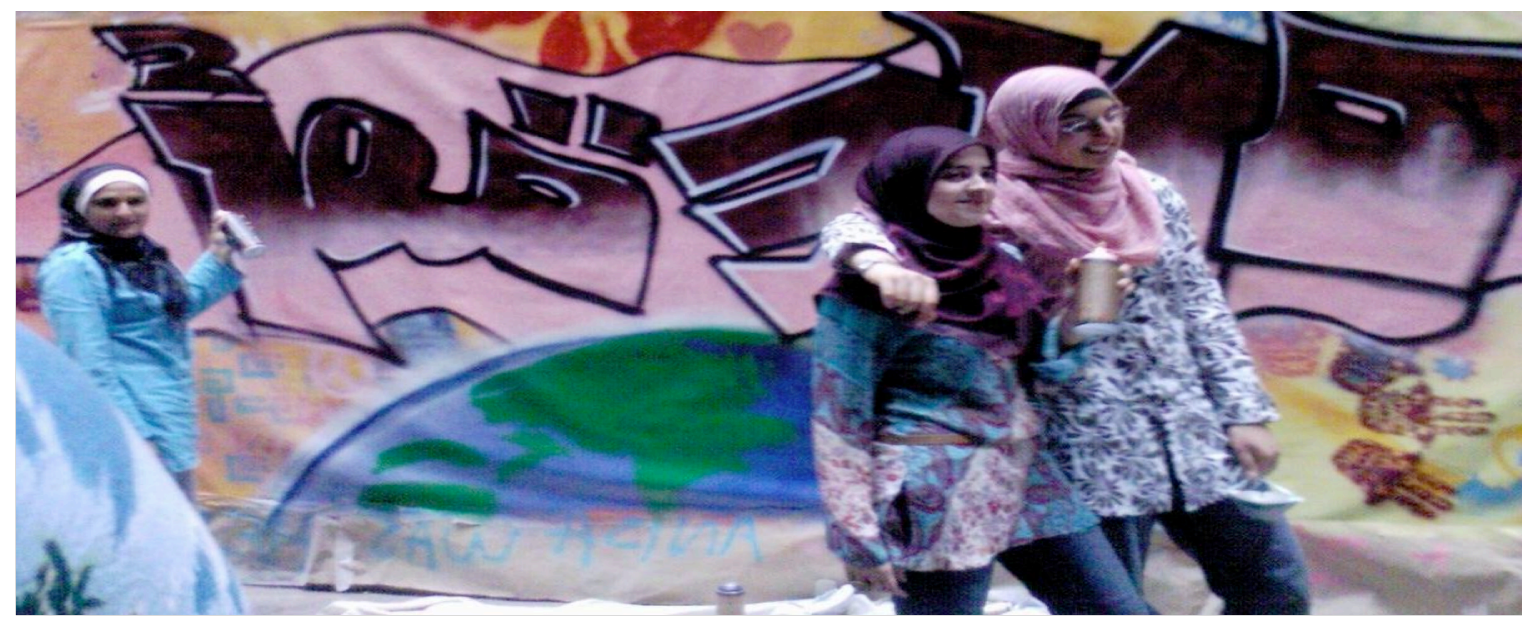

Figure 5 Crooked Rib create art at the Melbourne International Arts Festival, Sunday $26^{\text {th }}$ of October, 2008

\footnotetext{
${ }^{31}$ Jake Smallman and Carl Nyman, Stencil Graffiti Capital: Melbourne (2005) Mark Batty Publisher, West New York.

${ }^{32}$ Lonely Planet's Facebook Bluelist lists exploring Melbourne's laneways and street art as its number one culture fix or attraction http://www.facebook.com/topic.php?uid=11071120908\&topic=4488. See also http://www.lonelyplanet.tv/Clip.aspx?key=F3C2E8767A975C23
}

Public Space: The Journal of Law and Social Justice (2009) Vol 3, Art 3, p1-24. 


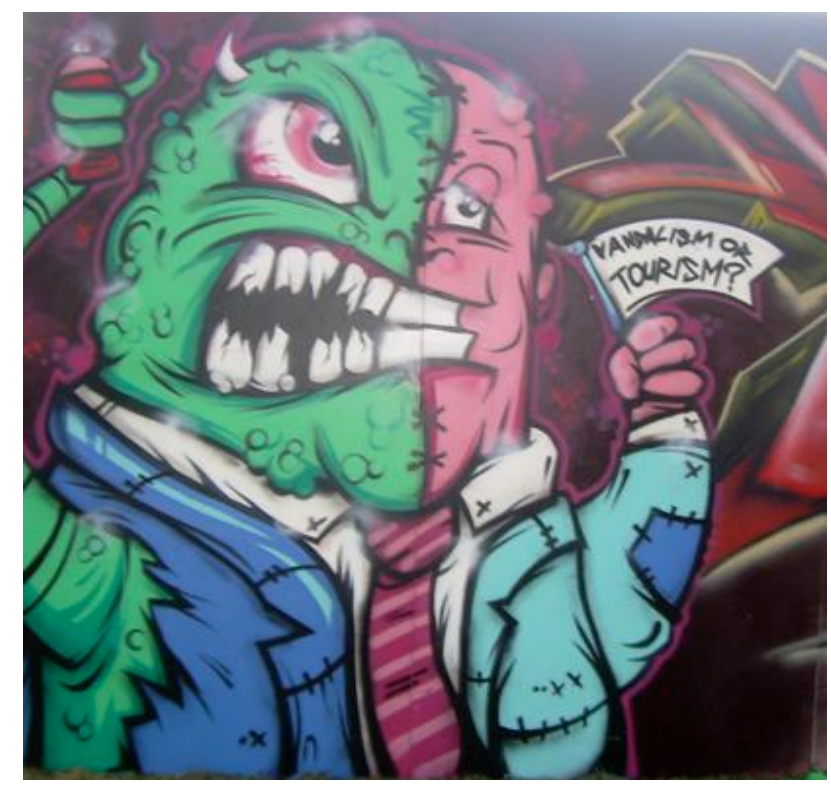

Melbourne street art. $^{33}$ The Melbourne Design Guide, which 'celebrates graffiti from a design perspective' was 'proudly' sponsored' by the state government. ${ }^{34}$ Local government also contributed financially to 'Stencil Fest' - a yearly ten day festival which displays stencil art by people who also regularly engage in Figure 6 'Vandalism or Tourism?' - Art 'illegal' stencil art - on the streets and lanes of created at 'Don't Ban the Can' Protest against the Graffiti Control Act, 21/10/08

Melbourne's inner suburbs. English artist 'Aerosol Ali' was brought out by Melbourne City Council's Community Cultural Development Program as part of the Melbourne International Arts Festival to create a graffiti mural with Crooked Rib in a Melbourne laneway. ${ }^{35}$

Street art was Melbourne's cache of cool, it was bringing tourists and their dollars; but some residents were unconvinced, leaving the Melbourne City council in a difficult position having to please those on two sides of an ever-widening chasm, driven wider by a wedge of moral panic. Ben Fordham, on A Current Affair, even described graffiti as 'organised crime'. ${ }^{36}$

The Melbourne City Council sought to preserve those aspects of street art that were recognised by the greater community as creative and aesthetically pleasing, while maintaining a strong stance against what was seen as less attractive forms such as tagging.

\footnotetext{
${ }^{33}$ View online at http://www.abc.net.au/tv/notquiteart/.

${ }^{34}$ Suzy Freeman-Greene, 'Urban Scrawl: Shades of Grey' The Age January 12, 2008.

${ }^{35}$ Crooked Rib are a group of 14 Muslim women graffiti artists. I saw their work in progress as part of the MIAF in 2008. See Arts Hub 'MIAF Special: Aerosol Arabic \& Crooked Rib' Monday, October 20, 2008 at http://www.artshub.com.au/au/news.asp?sId=174656\&ref=hubber.

${ }^{36} \mathrm{See} \mathrm{http://au.youtube.com/watch?v=A-S5mOtLYPk}$ accessed 21 November 2008.
} 
Research into the topic by council led to new graffiti management strategies ${ }^{37}$ that recognised a difference between 'street art' and 'graffiti.' Graffiti was usually linked with 'tagging' and street art with murals or alternatives such as stencils, stickers and paste-ups. Although often the same people engaged in more than one type of street art, an artificial distinction was constructed. While 'tagging' was 'ugly', 'street art' was creative - and increasing Melbourne's profile on the tourist map.

Melbourne city council's website states that:

The City of Melbourne recognises the importance of street art in contributing to a vibrant urban culture. Melbourne's street art has become internationally renowned and has become an attraction for local and overseas visitors experiencing Melbourne's creative ambience.

Council takes a strong stance against illegal graffiti and has a number of measures in place to ensure that the city stays clean. ${ }^{38}$

The strategies employed by the council are an effort 'to ensure that the city stays clean. ${ }^{, 39}$ That graffiti is equated with dirt or uncleanliness is a common response to graffiti, which is often connected with disease, plague, disruption to order and danger. ${ }^{40}$ However, 'legal street art' - although often indistinguishable to the passer by - contributes to the vibrancy of the urban centre.

In conjunction with the distinction between 'tagging' and other forms of street art, Melbourne city council sought new ways to control the location and content of street art. Although artists

\footnotetext{
37 Alison Young, Mark Halsey and Helen Forster, Draft Graffiti Management Strategy (2005) City of Melbourne.

${ }^{38}$ City of Melbourne Website at http://www.melbourne.vic.gov.au/info.cfm?top=145\&pg=3274 accessed 26 April 2009.

${ }^{39}$ Ibid.

${ }^{40}$ Alison Young, 'Written on the Skin of the City' in Judging the Image (2004) Routledge, London.
} 
within the street art scene, such as Ghost Patrol, insist that one of the essential qualities of street art is its ever changing, ephemeral nature, Melbourne City Council sought ways to align street art with more traditional forms of art, by accentuating its permanence. As Jeff Ferrell writes, '...spontaneity ... contributes to the threat which graffiti writing poses to those in authority. ${ }^{41}$ One way that council sought to preserve street art while controlling its spontaneity was by amending the Activities Local Law to create a permit system. ${ }^{42}$ This system, the only one of its kind in the world, also overcame the issue of permission. The applicant for the street art permit was the owner of the property - not the $\operatorname{artist}^{43}$ The applicant had to provide not only the street address, but also a 'sketch map' and colour photos (where the exact position of the art has been marked out in chalk or masking tape) showing the location of the proposed art. The application was more likely to succeed where the applicant also attached a description and sketch of the proposed artwork. These measures hopefully ensure the public that only the 'right' kind of imagery ends up on Melbourne's walls.

Although the permit system could be seen as stifling creativity, it was mostly looked upon favourably by street artists, who welcomed the recognition of the value of their work. The permit system was only on foot for a number of months before the introduction of the Graffiti Prevention Act, which saw the removal of all information on permits from the Melbourne City Council's website - besides the list of permits previously granted.

Apart from the permit system, the transformation of street art from ephemerality to permanence is exemplified by the Union Lane street art project. This project involved a legal mural being created by around 50 artists in November and December $2007 .^{44}$ The project is

\footnotetext{
${ }^{41}$ Jeff Ferrell n 4, p173.

${ }^{42}$ Activities Local Law Amendment (Street Art) Local Law 2006.

${ }^{43}$ Melbourne City Council Street Art Permit Fact Sheet (no longer online).

${ }^{44} \mathrm{http}: / /$ www.melbourne.vic.gov.au/info.cfm?top $=75 \& \mathrm{pa}=3128 \& \mathrm{pa} 2=3552 \& \mathrm{pg}=3859$.
} 
part of the city of Melbourne's graffiti management plan. ${ }^{45}$ Once the mural was completed, it was covered by an anti-graffiti coating at a cost of $\$ 50,000$ to ensure that the art in the laneway maintained its permanence - although it was indistinguishable to much illegal street art found in the city.

Another strategy to preserve the permanency of street art was the placing of a Perspex panel over Banksy's 'little diver' in Swanston Street. The stencil is rumoured to have been worth 'more than an average house. ${ }^{46}$ However, even with the coating, 'vandals' managed to destroy Banksy's art by pouring silver paint under the Perspex and scrawling 'Banksy woz ere' over the top. ${ }^{47}$ This 'vandalism' of Little Diver may have been a backlash against attempts to change the meaning of Banksy's work from a rebellious and ephemeral addition to public space, into a static tourist attraction/commodity a predictable and staged product within the city's aesthetic.

\section{Graffiti and the simulated city}

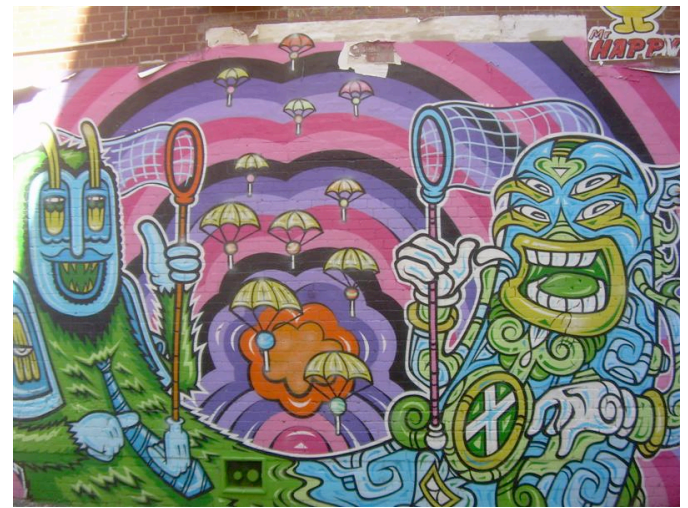

Figure 7 AC/DC Lane, Melbourne

Even when 'tamed', however, graffiti-styled imagery is at times considered a threat to authority, or at least as having the potential to 'tarnish' Melbourne's image. During the Florida Epcot Food and Wine festival in September 2008, Tourism Victoria and Walt Disney recreated the Victoria Market and a series of inner city laneways - complete with graffiti. The hyper-real simulation even had 'extras'. However, although the street art in Florida was only a copy of Melbourne graffiti, it advertised the city in a way that Victorian Premier John

\footnotetext{
45 Ibid.

${ }^{46}$ Jo Roberts, 'Could Laneway Graffiti be Worth More than your Average House?' The Age January 16, 2008 http://www.theage.com.au/articles/2008/01/15/1200159449775.html.

${ }^{47}$ Janae Houghton, 'The Painter Painted: Melbourne Looses its Treasured Banksy' The Age December 14, 2008 at http://www.theage.com.au/national/the-painter-painted-melbourne-loses-its-treasured-banksy-20081213$\underline{6 x z y \cdot h t m l}$.
}

Public Space: The Journal of Law and Social Justice (2009) Vol 3, Art 3, p1-24. 
Brumby found offensive. It was thus treated as if it were 'real' (criminal) graffiti. Premier Brumby commented: 'I don't think graffiti is what we want to be displaying overseas. We've put through very tough laws to discourage graffiti - it's a blight on the city. ${ }^{48}$ As Baudrillard theorised, in Simulacrum and Simulation, the postmodern era dissolves the distinctions between the 'real' and the 'simulated' so that the real no longer exists. ${ }^{49}$ In this example, the simulation of Melbourne in Florida contained the symbols of crime which were treated as 'real' graffiti and cleaned from the display.

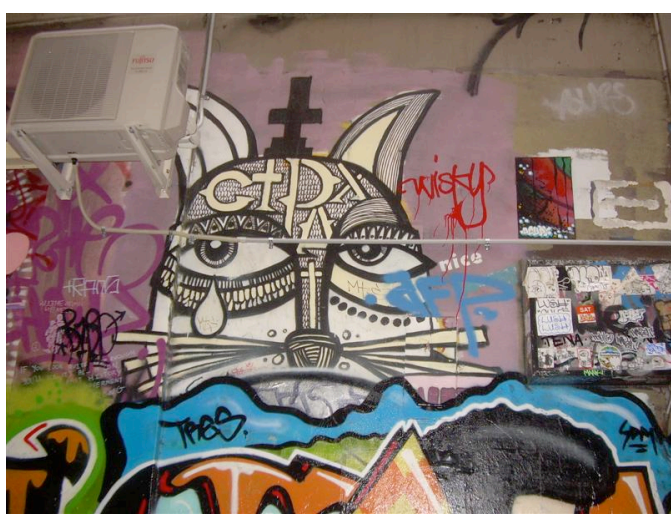

Figure 8 Hosier Lane
In a similar vein, Marc Ecko's 'Getting Up: Contents Under Pressure', a computer game about graffiti writing in which the player is rewarded for tagging, was banned in Australia. ${ }^{50}$ This virtual tagging creates no actual damage in the 'real' world,

but like the graffiti within the simulated 'Melbourne' in Florida, its imagery is seen as threatening - the reproduction of graffiti within cyberspace becoming indistinguishable from the real and hence eradicated from public (gamer) view. The film $70 K^{51}$ was also refused classification by the Office of Film and Literature Classification, for similar reasons. This non-narrative film depicted graffiti artists scrawling their tags throughout Melbourne to a rock soundtrack. Again, the existence of graffiti within the hyperreality of the cinema is responded to by authority as being menacing, and removed from public view via the refusal of classification.

\footnotetext{
${ }^{48}$ Jewel Topsfield 'Brumby Slams Tourism Victoria over Graffiti Promotion' The Age October 1, 2008.

${ }^{49}$ Jean Baudrillard (1996) Simulacra and Simulation University of Michigan Press, Michigan

${ }^{50}$ Australian Government Office of Film and Literature Classification see online at http://www.oflc.gov.au/.

${ }^{51} 70 \mathrm{k}$ stands for the crew 1970s kids - the crew of graffiti writers that artist Noam Shoan is a member of.
} 


\section{Commercialisation of the Image}

The relationship between graffiti and capitalism is complex and involves an exchange of ideas and imagery, resulting in an interplay of colours and styles. Lachlan McDowell argues that 'Much graffiti, particularly the tradition of tagging originating from New York ...provides a model for an individualised, highly mobile, geographically engaged subject that is not dissimilar from an ideal, late-capitalist consumer. ${ }^{, 52}$ Iain Sinclair writes: 'the [graffiti] tag is everything, as jealously defended as the Coke or Disney decals. Tags are the marginalia of corporate tribalism. Their offence is to parody the most visible aspect of high capitalist black magic. ${ }^{15}$ In this way, graffiti mimics commercial art, but contains different messages. Baudrillard writes: '...[G]raffiti runs contrary to all media and advertising signs, although they might create the illusion, on our city walls, that they are the same incantation. ${ }^{54}$ Graffiti's parody of commercial art runs both ways. Street artists are influenced by designs and colours from commercial art and billboards, and also by the very act of 'pushing' their own tag or identity into the spotlight. Commercial advertisers also frequently use graffiti imagery in their campaigns. Elements of graffiti art are appropriated as they lend an element of 'street cred' to an advertising campaign. One example of the appropriation of graffiti into advertising was its use in the Hummer 'Now Get Lost' promotion. Part of the commercial was photographed in Hosier Lane, Melbourne. Art curator Andy Mac asked Hummer on behalf of the artists to pay for the use of the imagery once it was taken off the wall and super-imposed onto the car (see Figure 7). Hummer chose not to pay the artists, but use 'generic graffiti'.

\footnotetext{
${ }^{52}$ Lachlan McDowell (2005) 'Graffitimedia: How graffiti functions as a model for new media futures' paper presented at Vital Signs: School of Creative Media National Conference September 7-9.

${ }^{53}$ Iain Sinclair cited ibid.

${ }^{54}$ Baudrillard n 14, p79.

${ }^{55}$ Andy MacDonald speaking at a graffiti forum at the Famous when Dead Gallery, North Melbourne, 6 April 2008 .
}

Public Space: The Journal of Law and Social Justice (2009) Vol 3, Art 3, p1-24. 


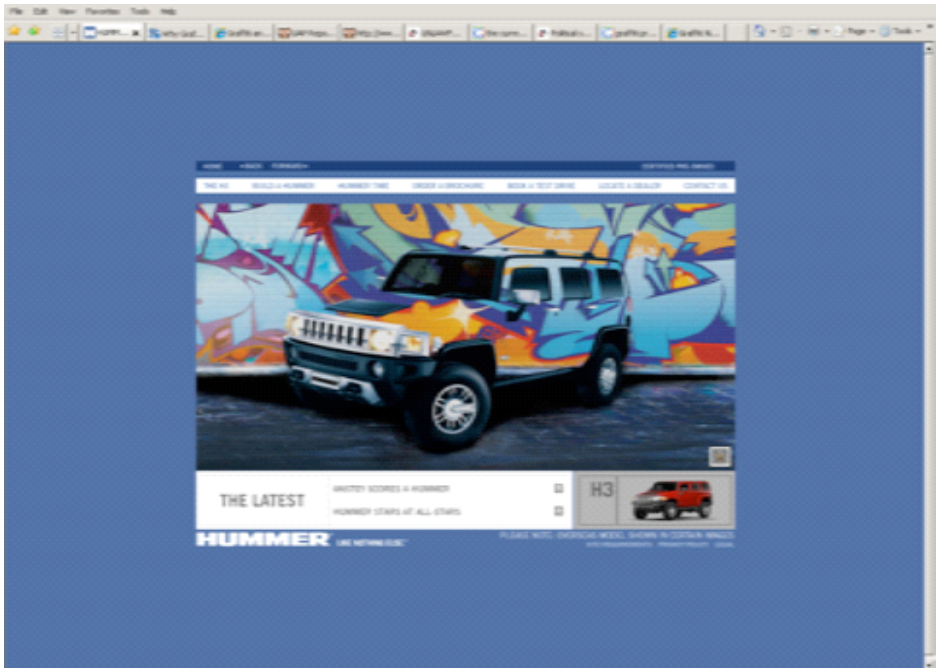

Figure 9 Hummer 'Now Get Lost' Advertising Campaign Online

Graffiti Prevention Act (Vic) 2007

The Graffiti Prevention Bill was passed in late 2007. Outrage following what was seen by some as lenient sentencing ${ }^{56}$ and pressure from vocal minorities such as RAGE and Graffiti Hurts Australia $^{57} \quad-$ as well as conservative forces within the government - heralded the push toward making graffiti its own category of criminal damage. Now, not only can the artist be charged with damage to property under the Summary Offences or Crimes Act, ${ }^{58}$ but be also charged with 'marking graffiti' under the new Act. ${ }^{59}$

One aspect of the Act which is of particular concern is the reversal of the burden of proof. The burden of proof in criminal cases usually lies with the prosecution - which is a central pillar of our legal system and a right set out in the Victorian Charter of Human Rights and Responsibilities. ${ }^{60}$ The Graffiti Prevention Act allows for search without a warrant upon 'reasonable grounds'. ${ }^{61}$ Those found carrying implements such as textas or aerosol paint cans must prove that they need the implements for a purpose other than graffiti - put another way, they are guilty until proven innocent. ${ }^{62}$ There are many lawful uses for these so-called

\footnotetext{
${ }^{56}$ For example PALS, People Against Lenient Sentencing, see: http://palsforjustice.com/news.php, or Victoria Parliamentary Debates n 24.

${ }^{57}$ See http://www.graffitihurts.com.au/.

${ }^{58}$ Summary Offences Act (Vic) 1966 s 10; Crimes Act (Vic) 1958 (Vic) s 197.

${ }^{59}$ Graffiti Prevention Act (Vic) 2007 s 5

${ }^{60}$ Victorian Charter of Human Rights and Responsibilities Act (Vic) 2006.

${ }^{61} \mathrm{~s} 12$ and s 13. Underage persons may be searched under the Act, although with some restrictions.

${ }^{62}$ This is an aspect of the legislation which has come under fire, even from local councils who have a 'zero tolerance' response to graffiti (eg Moreland city council - see minutes of council meeting 14 February 2007 accessed at http://www.moreland.vic.gov.au/council/minutes/minutes2004-2008/cm140207.htm on 19 February 2008 .
}

Public Space: The Journal of Law and Social Justice (2009) Vol 3, Art 3, p1-24. 
'graffiti implements' and this is strong punishment for their possession. Being found in possession of a 'graffiti implement' has a penalty of 25 penalty units, or $\$ 2,835.50$. If a person is 'present in or near - a) a location with a high incidence of graffiti or b) a location that appears to have been recently marked with graffiti ${ }^{63}$ this may be sufficient reason for search without a warrant. This is particularly disturbing where persons as young as 14 can be searched. Train stations or surrounds, and many Melbourne streets would fit the description of a 'location with a high incidence of graffiti'.

Punishment for graffiti is severe - up to 2 years jail and a $\$ 27,220.80$ fine. Graffiti is defined as anything which involves marking a surface which cannot be easily wiped off with a dry cloth. ${ }^{64}$ Where graffiti is on private property, 'A council may...take any action necessary to remove or obliterate graffiti on private property if graffiti is visible from a public place. ${ }^{65}$

\section{Legal developments since the passing of the Graffiti} Prevention Act (Vic) 2007

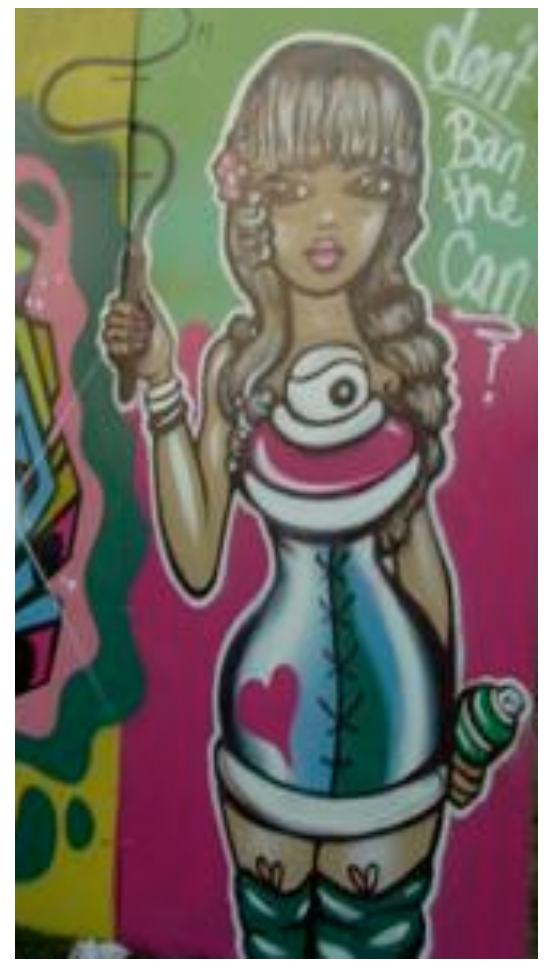

Since the Graffiti Prevention Act was passed in Victoria, there have been a number of legal developments. The permit Figure 10 Don't Ban the Can - Art from the Protest system, which attempted to tame the spontaneity of street art, has now been modified by the Activities (Street Art) Local Law 2009. One purpose of the amendment to the Activities Local Law is to: 'ensure consistency with the Graffiti Prevention Act 2008'. The amendment does

\footnotetext{
${ }^{63}$ Graffiti Prevention Act (Vic) 2007 s 13.

${ }^{64} \mathrm{~s} 2$.

${ }^{65} \mathrm{~s} 18$.
}

Public Space: The Journal of Law and Social Justice (2009) Vol 3, Art 3, p1-24. 
allow street art which is executed 'in accordance with a permit.' However, only 'murals' can be street art. Tagging and 'stand alone stencils' cannot. ${ }^{66}$

New South Wales has also followed Victoria, passing its own legislation specifically criminalising graffiti. The Graffiti Control Act (NSW) 2008 is similar in content to the Victorian legislation. Cheyene Back, an 18 year old writer, was sentenced to three months imprisonment under the Act for scrawling her nick name on a cafe wall with a marker. ${ }^{67}$ The conviction and prison term were, however, overturned on appeal. ${ }^{68}$ The Act itself stipulates at s 4(2) that 'A court ... must not sentence the person to imprisonment unless the person has previously been convicted of an offence under this section or section $5 \ldots$ on so many occasions that the court is satisfied that the person is a serious and persistent offender and is likely to commit such an offence again. ${ }^{69}$ Obviously, this provision did not influence the magistrate in sentencing Black - this was her first offence - but still resulted in conviction and imprisonment. Back was guilty of more than just markings on a wall - she was an 'aesthetic saboteur.'

\footnotetext{
${ }^{66}$ However, Banksy's 'Little Diver' is a stand-alone mural, prompting the question of whether it would be considered street art or graffiti under the new law, had it not been painted over.

${ }^{67}$ Harriet Alexander (2009) 'Graffiti Girl Wins Appeal Against Jail Term' Sydney Morning Herald March 4, 2009. Accessed online at http://www.smh.com.au/national/graffiti-girl-wins-appeal-against-jail-200903048nxd.html on April 262009.

${ }^{68}$ Ibid.

${ }^{69}$ Graffiti Control Act (NSW) 2009 s 4(2).
} 


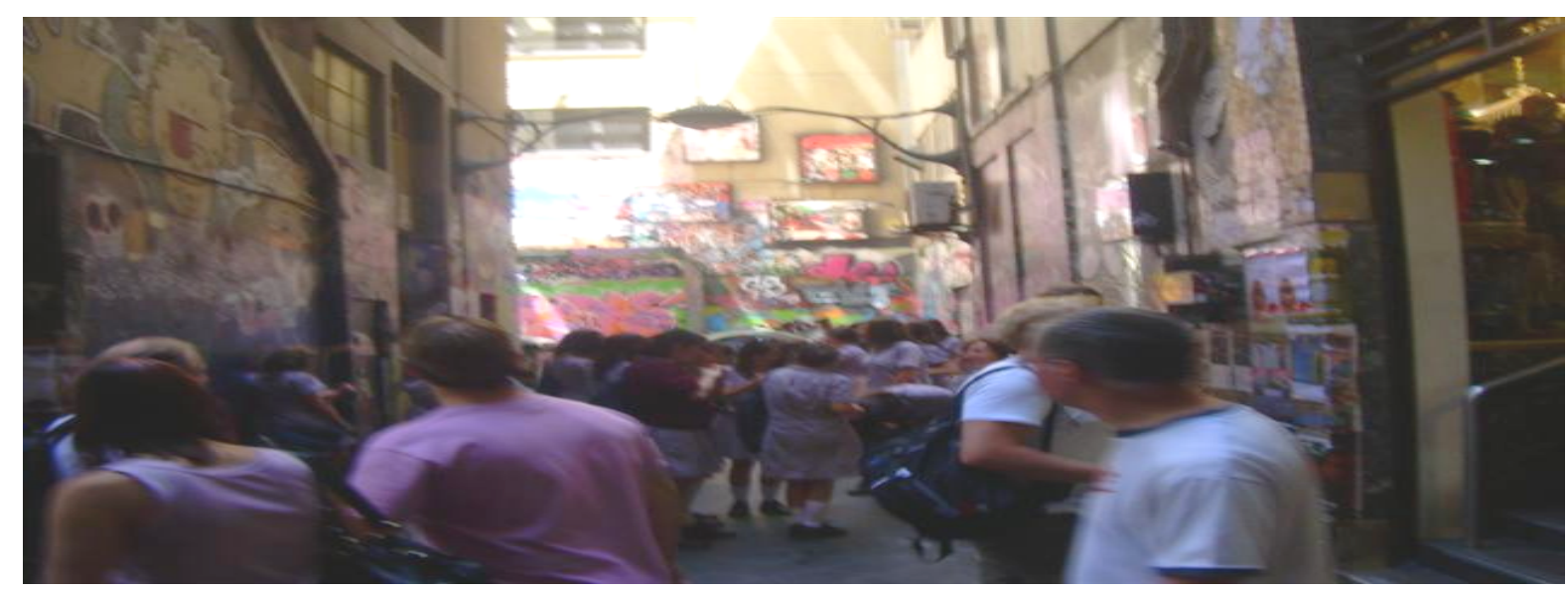

Figure 11 School children and tourists observe graffiti in Centre Place, Melbourne

\section{Conclusion}

Graffiti writing breaks the hegemonic hold of corporate/governmental style over the urban environment and the situations of daily life. As a form of aesthetic sabotage, it interrupts the pleasant, efficient uniformity of 'planned' urban space and predictable urban living. ${ }^{70}$

In this paper I have discussed legal responses to graffiti in the context of its affects/effects on the aesthetics of the city. Graffiti is dangerous because it symbolises lack of order, and blurs boundaries rigidly enacted by property law. As Halsey and Young write '...graffiti's authors write in ways which rupture orthodox senses of urbanity - of order, cleanliness, purity, integrity and so forth. ${ }^{71}$ Graffiti, or its less menacing meme, street art, confronts ingrained ideas about public space, and who has rights to determine its use and meaning. As Jeff Ferrell asks, why is a wall with graffiti considered 'uglier' than one without it? And who has a right to make this choice? Public art must not interrupt the 'aesthetics of authority' or it is rendered illegal vandalism by the state.

\footnotetext{
${ }^{70}$ Jeff Ferrell n 4, p176

${ }^{71}$ Halsey and Young n 6, p296.

Public Space: The Journal of Law and Social Justice (2009) Vol 3, Art 3, p1-24.
} 
In the postmodern era, capitalism is marked less by the ownership of the means of production but rather centres on the control of subjectivity through signs, media and advertising, for example. ${ }^{72}$ Within post-industrial capitalism, or the age of integrated world capitalism, ${ }^{73}$ all aspects of daily life are subsumed. However, power is always incomplete. There are always nodes of resistance. For Baudrillard, graffiti can provide at least a disruption to the codes of the capitalist city, and the potential to dissolve its structures at the level of meanings. In the words of Baudrillard:

We must attack...by means of difference, dismantling the network of codes, attacking coded differences by means of an uncodeable absolute difference, over which the system will stumble and disintegrate. There is no need for organised masses, nor for a political consciousness to do this - a thousand youths armed with marker pens and cans of spray-paint are enough to scramble the signals of urbania and dismantle the order of signs. $^{74}$

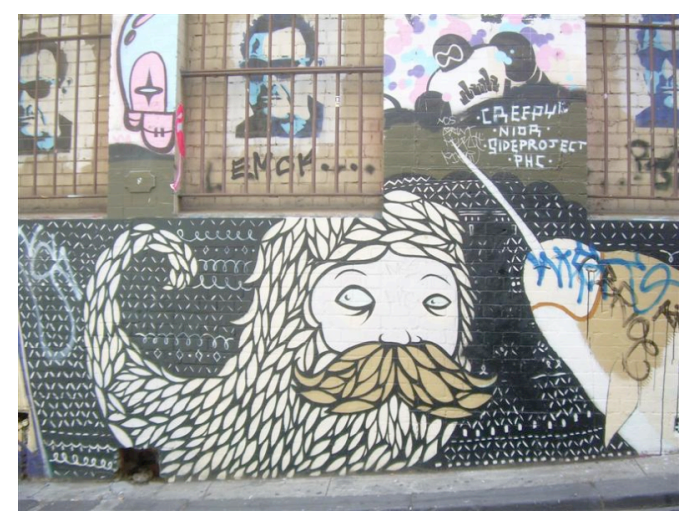

\footnotetext{
${ }^{72}$ Guattari n 7, p137.

${ }^{73}$ Ibid.

${ }^{74}$ Baudrillard n 14, p80-81.
} 


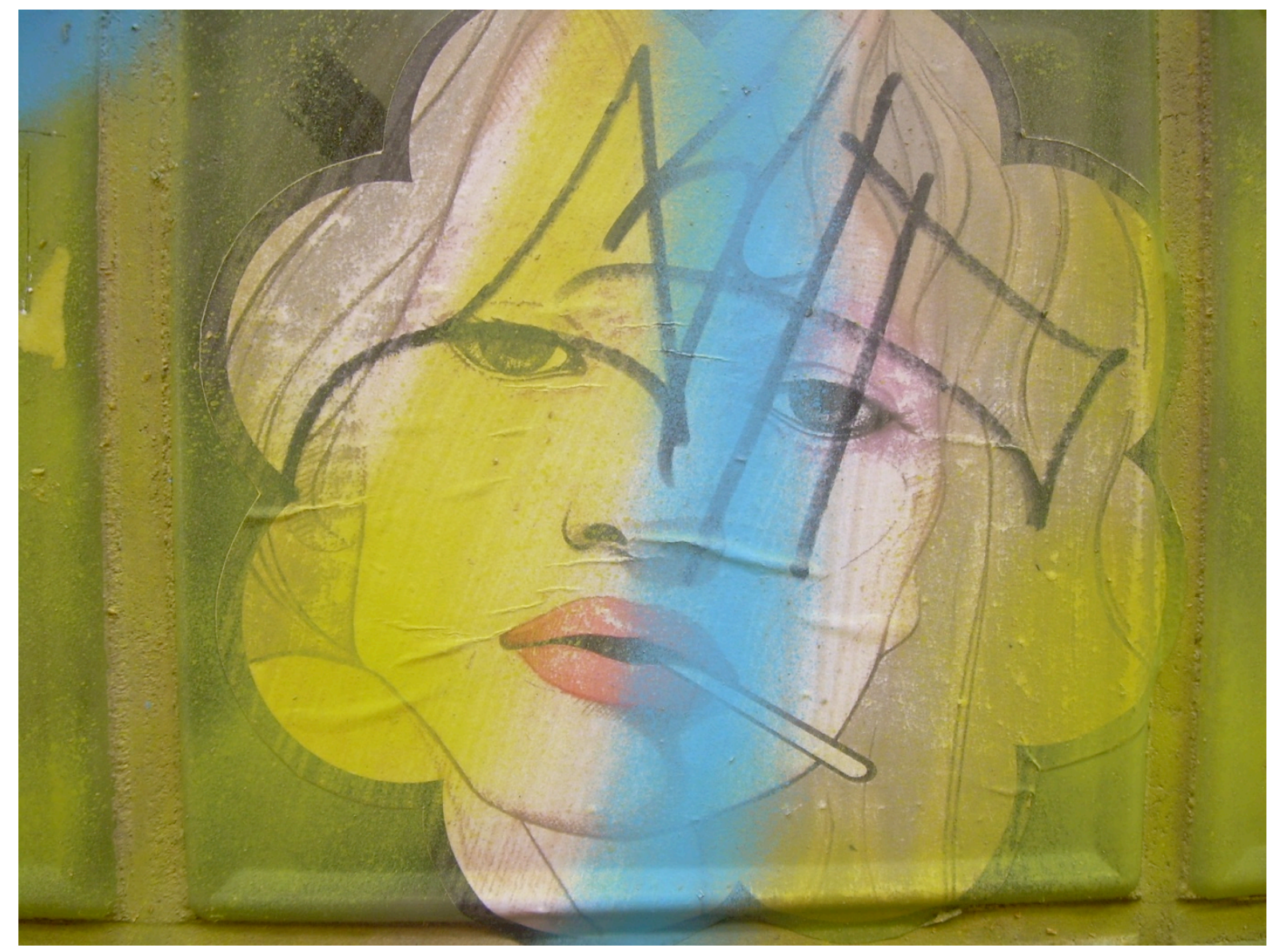

\section{Bibliography}

Harriet Alexander 'Graffiti Girl Wins Appeal Against Jail' Sydney Morning Herald March 4 2009

Arts Hub 'MIAF Special: Aerosol Arabic \& Crooked Rib' Monday, October 20, 2008 at http://www.artshub.com.au/au/news.asp?sId=174656\&ref=hubber

Jean Baudrillard (1996) Simulacra and Simulation University of Michigan Press

Jean Baudrillard (1993) 'Kool Killer, or The Insurrection of Signs' Symbolic Exchange and Death Sage

City of Melbourne Website at:

Public Space: The Journal of Law and Social Justice (2009) Vol 3, Art 3, p1-24. 
$<\underline{\text { http://www.melbourne.vic.gov.au/info.cfm?top=145\&pg=3274 }>}$

City of Melbourne 'A New Approach to Street Art: What You Need to Know' May 2007

Tim Creswell, 'The Crucial "Where" of Graffiti' in In Place/Out of Place: Geography, Ideology, Transgression (1996) University of Minnesota Press

Margaret Davies, Asking the Law Question ( ${ }^{\text {rd }}$ edition 2008) Lawbook Co

Liven de Cauter, The Capsular Civilization: On The City in the Age of Fear (2004) NAi Publishers

Jeff Ferrell, Crimes of Style: Urban Graffiti and the Politics of Criminality (1996) Garland

Suzy Freeman-Greene, 'Urban Scrawl: Shades of Grey’ The Age January 12, 2008

Felix Guattari, The Three Ecologies, (1989) 8 New Formations 131

Graffiti Hurts Australia Website: < $\underline{\text { http://www.graffitihurts.com.au/ }>}$

Mark Halsey and Alison Young (2006) 'Our Desires are Ungovernable' Theoretical Criminology 10(3)

Janae Houghton, 'The Painter Painted: Melbourne Looses its Treasured Banksy' The Age December 14, 2008

Kate Jones, 'Graffiti Vandal "now Bird Watcher”" Herald-Sun August 4, 2007

Carolyn Korsmeyer (ed) Aesthetics: The Big Questions (1999) Blackwell

Henri Lefebvre, The Production of Space (1991) Blackwell

People Against Lenient Sentencing website: $<\underline{\text { http://palsforjustice.com/news.php }>}$

Residents Against Graffiti Everywhere (RAGE) Website:

Public Space: The Journal of Law and Social Justice (2009) Vol 3, Art 3, p1-24. 
$<\underline{\text { http://au.geocities.com/ragepages/index.html }>}$

Brendan Roberts, 'Jail for Graffiti' Herald-Sun August 23, 2007

Jo Roberts, 'Could Laneway Graffiti be Worth More than your Average House?' The Age January 16, $2008<\underline{\text { http://www.theage.com.au/articles/2008/01/15/1200159449775.html }>}$

Jake Smallman and Carl Nyman, Stencil Graffiti Capital: Melbourne (2005) Mark Batty Publisher West

Jewel Topsfield ‘Brumby Slams Tourism Victoria over Graffiti Promotion' The Age October 1,2008

Alison Young, Mark Halsey and Helen Forster, Draft Graffiti Management Strategy (2005) City of Melbourne

Alison Young 'Written on the Skin of the City' in Judging the Image (2004) Routledge ABC Television 'Ron English' Triple J TV Australian Broadcasting Commission, broadcast April 24, 2009

ABC Television 'Papercuts: The Art of Ghostpatrol and Miso' February 24, 2009

ABC Television 'Not Quite Art' October 16, 2007 <http://www.abc.net.au/tv/notquiteart/>

Pedro Carvajal (2006) Popaganda: The Art and Crimes of Ron English Cinema Libre

Gary Ross (1998) Pleasantville Newline Cinema

Courtney v Yarra City Council [2004] VCAT 865

Crimes Act (Vic) 1958

DPP v Shoan [2007] VSCA 220

Public Space: The Journal of Law and Social Justice (2009) Vol 3, Art 3, p1-24. 
Graffiti Prevention Act (Vic) 2007

Melbourne City Council Activities Local Law Amendment (Street Art) Local Law 2006

Melbourne City Council Activities (Street Art) Local Law 2009

Melbourne City Council Activities Local Law 1999

Summary Offences Act (Vic) 1966

Victoria Parliamentary Debates, Legislative Assembly, 23 August 2007, 2936 (Ken Smith)

Victorian Charter of Human Rights and Responsibilities Act (Vic) 2006

Public Space: The Journal of Law and Social Justice (2009) Vol 3, Art 3, p1-24. 